\title{
PENGARUH PENAMBAHAN CACING SUTRA (Tubifex) SEBAGAI KOMBINASI PAKAN BUATAN TERHADAP EFISIENSI PEMANFAATAN PAKAN DAN PERTUMBUHAN LARVA IKAN LELE SANGKURIANG
} (Clarias gariepinus)

\section{THE EFFECT OF SLUDGE WORMS (Tubifex) COMBINED WITH ARTIFICIAL FEED ON FEED AFFICIENCY AND GROWTH OF AFRICAN CATFISH LARVAE (Clarias gariepinus)}

\author{
Atta Mullah $^{1 *)}$, Nanda Diniarti ${ }^{1)}$, Baiq Hilda Astriana ${ }^{1)}$ \\ ${ }^{1)}$ Program Studi Budidaya Perairan, Fakultas Pertanian, Universitas Mataram
}

\begin{abstract}
Abstrak
Ikan lele (Clarias sp.) merupakan salah satu komoditas air tawar unggulan untuk dibudidayakan dan digemari di kalangan masyarakat. Hal ini dikarnakan nutrisi yang dimiliki ikan lele mengandung protein yang tinggi dan zat penguat tulang (kalsium) yang baik untuk makanan. Ikan lele termasuk dalam golongan ikan karnivora dan juga termasuk hewan pemakan bangkai, pada fase larva ikan lele sangat membutuhkan pakan alami seperti cacing sutra (Tubifex) yang memiliki nilai protein yang tinggi. Penelitian ini dilaksanakan selama 30 hari dari Tanggal 31 Juli 2019 sampai Tanggal 29 Agustus 2019, tempat penelitian dilaksanakan di Desa Langko, Kecamatan Lingsar, Kabupaten Lombok Barat. Penelitian ini dilakukan dengan metode eksperimental menggunakan Rancangan Acak Lengkap (RAL) dengan empat perlakuan dan tiga ulangan yaitu perlakuan A: Pelet 100\% (kontrol), B : Pelet 25\% dan Cacing Sutra 75\%, C : Pelet 50\% dan Cacing Sutra 50\% dan D : Pelet $75 \%$ dan Cacing Sutra 25\%. Hasil penelitian menunjukkan bahwa tingkat kelangsungan hidup (SR) larva ikan lele sangkuriang (Clarias gariepinus) tertinggi diperoleh pada perlakuan B yaitu mencapai $94,7 \%$ dan nilai kelangsungan hidup terendah pada perlakuan A yaitu sebesar $80 \%$. Hasil ANOVA menunjukan ada perbedaan signifikan dari pengaruh penambahan cacing sutra sebagai kombinasi pakan buatan untuk pemeliharaan terhadap pertumbuhan berat mutlak, pertumbuhan panjang mutlak, tingkat kelangsungan hidup, efisiensi pemanfaatan pakan (EPP) dan waktu pengosongan lambung. Perlakuan terbaik diperoleh perlakuan B (Pelet 25\% dan Cacing Sutra 75\%).
\end{abstract}

Kata Kunci: Ikan Lele, Cacing Sutra, Pelet, EPP

\begin{abstract}
Catfish (Clarias sp.) Is one of the commodities featured fresh water to be cultivated and popular among the people. This dikarnakan owned catfish nutrition high in protein and bonefortifying substances (calcium) is good for food. Catfish (Clarias sp.) included in the class of carnivorous fish and also includes scavengers, at the larval stages of catfish in desperate need of natural food such as sludge worms (Tubifex), which has a high protein value, The research was conducted for 30 days from the date July 31, 2019 until the date August 29, 2019, where research is conducted in the village of Langko, District Lingsar, West Lombok regency, This research was conducted with an experimental method using a completely randomized design (CRD) with four treatments and three replications that treatment A: Pellet 100\% (control), B: Pellets $25 \%$ and sludge worms $75 \%$, C: Pellet $50 \%$ and sludge worms $50 \%$ and D: Pellets $75 \%$ and $25 \%$ sludge worms. The results showed that larval fish catfish (Clarias gariepinus)

*korespondensi: attamullah743@gmail.com
\end{abstract}


the survival rate (SR) was obtained in treatment B the highest, reaching $94.7 \%$ and the value of the lowest survival in treatment $\mathrm{A}$ is equal to $80 \%$. ANOVA results showed no significant difference from the effect of the addition of sludge worms (Tubifex) as a combination of artificial feed for the maintenance of of the weight growth absolute length growth the absolute level of lifespan life, the efficiency of feed utilization and the emptying time hull.

Keywords: Catfish, sludge worms, Pellets, Feed On Feed Afficiency

\section{Pendahuluan}

Ikan lele (Clarias sp.) merupakan ikan yang hidup di perairan tawar, dengan arus yang tidak deras atau perairan yang tenang. Ikan lele termasuk dalam golongan ikan karnivora dan juga termasuk hewan pemakan bangkai. Ikan lele merupakan salah satu komoditas air tawar unggulan untuk dibudidayakan (Mahyuddin, 2008 dalam Nisrinah et al., 2013). Hal ini dikarenakan nutrisi yang dimiliki ikan lele mengandung protein yang tinggi dan zat penguat tulang (kalsium) yang baik untuk makanan (Apriyana, 2013). Menurut KKP (2019), tahun 2018 volume produksi ikan lele dari sentra-sentra budidaya mencapai $85.496,85$ ton naik 79,15 persen dari tahun sebelumnya sebesar $67.671,84$ ton. Nilai produksinya pun meningkat dari $\mathrm{Rp}$ 996.975.580.000 menjadi Rp 1.336.963.249.000 atau naik 74,57 persen pada periode yang sama.

Menurut pendapat dari Nurhayati et al. (2014), tingginya permintaan terhadap ikan lele sehingga banyak pembudidaya ikan lele yang melakukan pembenihan secara buatan agar benih ikan lele selalu tersedia saat dibutuhkan untuk proses budidaya dan juga agar meningkatkan kualitas benih. Stadium larva sangat penting dan kritis karena pada stadium ini larva sangat sensitif terhadap ketersediaan makanan. Sebagaimana hewan lainnya larva ikan lele memiliki sistem pencernaan yang masih sederhana dan belum berdiferensiasi baik secara morfologi maupun secara fisiologis, sehingga diperlukan pemberian pakan alami.

Jenis pakan yang dikonsumsi dapat berupa pakan alami dan pakan buatan yang mengandung nutrien yang sesuai dengan kebutuhan ikan. Ikan lele yang masih berukuran larva sampai benih memembutuhkan pakan alami yang mencukupi.Pertumbuhan sangat dipenuhi oleh faktor nutrisi yang diperoleh dari pakan. Pakan termasuk salah satu aspek penting yang harus diperhatikan dalam kegiatan budidaya, karna pakan merupakan sumber energi untuk menunjang pertumbuhan. Pakan yang baik merupakan pakan yang sesuai dengan kebutuhan fisiologi dan spesies ikan yang dibudidayakan disamping mampu untuk memenuhi kebutuhan nutrisi ikan tersebut (Ariefet al., 2014).

Salah satu contoh pakan alami untuk larva lele adalah cacing sutra. Menurut Setiawati et al. (2014), cacing sutra adalah salah satu jenis pakan alami yang baik bagi pertumbuhan ikan yang mempunyai kandungan gizi yang cukup tinggi, yaitu dengan protein sekitar $57 \%$ dan diberikan dalam keadaan hidup sehingga disenangi oleh ikan. Cacing sutra termasuk hewan tingkat rendah, karena tidak memiliki tulang belakang (unvertebrata) dan dimasukkan dalam filum Annelida, kelas Oligocheata. Selain itu, cacing sutra mudah dicerna serta diserap oleh dinding usus pemakannya. Menurut hasil penelitian Nurhayati et al. (2014), pemberian pakan buatan (PB) $100 \%$ memiliki nilai terkecil untuk sintasan yaitu $66,44 \%$, demikian pula dengan pertumbuhan panjang dan laju pertumbuhan spesifik yaitu 19,94 $(\mathrm{p}<0,05)$, sehingga dibutuhkan kombinasi pakan yang cocok untuk larva ikan lele.

Pengaruh penambahan cacing sutra pada pakan buatan dan probiotik pernah dilakukan dalam penelitian Anggrainy (2015) pada pemeliharaan larva ikan lele 
dumbo, didapatkan perlakuan cacing sutra $100 \%$ menghasilkan nilai sintasan yaitu 95\%, pertambahan panjang $2,5 \mathrm{~cm}$ dan pertumbuhan bobot rataan mencapai $0,21 \mathrm{~g}$ dalam 15 hari pemeliharaan. Ditambahkan pula oleh Bokings et al. (2017) yang mengombinasikan pakan buatan dengan cacing sutra untuk pertumbuhan dan kelangsungan hidup ikan patin siam, dimana perlakuan $100 \%$ cacing sutra memberikan pertumbuhan terbaik menghasilkan pertambahan panjang dan berat tertinggi sebesar $1,89 \mathrm{~cm}$ dan dan $0,74 \mathrm{~g}$ yang dipelihara selama 5 minggu. Walaupun demikian untuk penelitian mengenai penambahan cacing sutra sebagai kombinasi pakan buatan pada pemeliharaan larva ikan lele sangkuriang belum pernah dilakukan. Oleh karna itu perlu dilakukan penelitian tentangpengaruh penambahan cacing sutra sebagai kombinasi pakan buatan terhadap efisiensi pemanfaatan pakan dan pertumbuhan larva ikan lele sangkuriang (Clarias gariepinus).

Tujuan dari penelitian adalah untuk mengetahui pengaruh dari penambahan cacing sutra (Tubifex) sebagai kombinasi pakan buatan terhadap efisiensi pemanfaatan pakan dan pertumbuhan larva ikan lele sangkuriang (Clarias gariepinus).

\section{Metode}

\section{Waktu dan Tempat}

Penelitian ini dilaksanakan selama 30 hari dari Tanggal 31 Juli 2019 sampai tanggal 29 Agustus 2019. Pelaksanaan penelitian dilaksanakan di Desa Langko, Kecamatan Lingsar, Kabupaten Lombok Barat, Provinsi Nusa Tenggara Barat.

\section{Alat-alat Penelitian}

Adapun alat yang digunakan yaitu, Alat seperti Toples, Aertator, Timbangan analitik, Jangka sorong, pH meter, Termometer, dan Spektrofotometer.

\section{Bahan-bahan Penelitian}

Adapun bahan yang digunakan yaitu, Larva ikan lele sangkuriang berumur 4 hari dengan bobot 0,02 g/ekor dan panjang
1,07-1,15 cm, Cacing sutra, Pakan komersil, Air tawar, Akuades, Sabun anti septik dan Titrasi wikler.

\section{Rancangan Penelitian}

Rancangan percobaan yang digunakan dalam penelitian adalah Rancangan Acak Lengkap (RAL) dengan menggunakan 4 perlakuan dan masingmasing 3 ulangan, sehingga banyaknya satuan percobaan adalah 12 unit. Adapun perlakuan yang digunakan mengacu pada penelitian Nurhayati et al. (2014), dan untuk penelitian ini perlakuan yang digunakan adalah sebagai berikut:
$\mathrm{A}=$ Pelet $100 \%$ (Kontrol)
$\mathrm{B}=$ Kombinasi Pelet $25 \%$ dan Cacing Sutra $75 \%$
$\mathrm{C}=$ Kombinasi Pelet $50 \%$ dan Cacing Sutra $50 \%$
D = Kombinasi Pelet $75 \%$ dan Cacing Sutra $25 \%$

\section{Prosedur Kerja}

Kepadatan larva ikan lele mengacu dari penelitian Nurhayati et al. (2014), dengan kepadatan 20 ekor dalam 1 litar air yang artinya setiap wadah diisi 200 ekor larva ikan lele dalam 10 liter air.

Selama masa pemeliharaan, larva ikan lele diberikan pakan berupa Pakan komersil dan cacing sutra. Menurut Nurhayati et al.(2014), pakan komersil dan cacing sutra sebanyak 5\% dari bobot biomassa per hari sesuai dengan perlakuan. Cacing sutra diberikan dalam bobot basah dengan frekuensi pemberian pakan 4 kali sehari, yaitu pukul 08.00-09.00, 12.0013.00, 16.00-17.00, dan 21.00-22.00 WITA. Sebelum cacing sutra diberikan kepada ikan, cacing harus dibersihkan terlebih dahulu dan dicampurkan sesuai dengan perlakuan. Perhitungan jumlah pemberian pakan dilakukan dengan carapenimbangan bobot larva lelesetiap 7 hari sekali dan hasilnya dikalikan 5\%, dinyatakan menurut Nurhayati et al.(2014) dengan rumus:

$\mathrm{TPP}=5 \% \mathrm{x}$ Jumlah bobot ikan

Keterangan: 
TPP : Jumlah pemberian pakan

Pengukuran kualitas air dilakukan pada pagi hari yaitu pada jam 06.00-07.00 WITA sebelum ikan diberikan pakan. Kualitas air yang diukur yaitu: $\mathrm{pH}$, suhu, DO dan amoniak.

\section{Parameter Pengamatan}

a) Pertumbuhan Berat Mutlak

Keterangan :

$$
\mathrm{W}=\mathrm{Wt}-\mathrm{Wo}
$$

$\mathrm{W}=$ Pertambahan berat $(\mathrm{g})$

$\mathrm{Wt}=$ Berat lele uji pada akhir penelitian $(\mathrm{g})$

$\mathrm{Wo}=$ Berat lele uji pada awal penelitian (g)

b) Pertumbuhan Panjang Mutlak

Keterangan :

$$
\mathrm{L}=\mathrm{L} 1-\mathrm{L} 2
$$

$\mathrm{L}=$ Panjang mutlak

$\mathrm{L} 2=$ Panjang rata-rata akhir $(\mathrm{cm})$

$\mathrm{L} 1=$ Panjang rata-rata awal $(\mathrm{cm})$

c) Tingkat Kelangsungan Hidup (Survival Rate)

$$
\mathrm{SR}=\frac{N t}{N o} \times 100 \%
$$

Keterangan :

$\mathrm{SR}=$ Tingkat kelangsungan hidup $(\%)$

$\mathrm{Nt}=$ Jumlah ikan yang mati selama penelitian (ekor)

$\mathrm{No}=$ Jumlah awal penebaran (ekor)

d) Efesiensi Pemanfaatan Pakan (EPP)

$$
\mathrm{EPP}=\frac{\mathrm{Wt}-\mathrm{Wo}}{\mathrm{F}} \times 100 \%
$$

\section{Keterangan:}

$\mathrm{EPP}=$ Efesiensi pemanfaatan pakan

$\mathrm{Wt}=$ Berat total ikan pada akhir penelitian $(\mathrm{g})$

Wo = Berat total ikan pada awal penelitian $(\mathrm{g})$

$\mathrm{F} \quad=$ Jumlah pakan yang diberikan selama proses penelitian.

e) Waktu Pengosongan Lambung

Metode yang digunakan untuk mengukur waktu pengosongan lambung yaitu dengan cara ikan diberikan pakan sesuai dengan perlakuan kemudian diamati berapa lama ikan mengeluarkan feses dari saat ikan memakan pakan yang diberikan.

\section{Analisis Data}

Analisis data merupakan proses untuk menyederhanakan kembali data-data yang diperoleh agar mudah dipahami dan diinterpretasikan secara mendalamterhadap hasil penelitian yang dilakukan. Analisis data yang dilakukan dalampenelitian ini meliputi efesiensi pemanfaatan pakan, pertumbuhan, kelangsungan hidup, waktu pengosongan lambung dan kualitas air. Data yang diperoleh dianalisis menggunakan analisis sidik ragam (ANOVA) pada taraf nyata 5\%. Setiap parameter uji menunjukkan signifikan maka dilakukan uji lanjut BNT (Beda Nyata Terkecil), karna nilai koefisiensi keseragaman (KK) pada setiap parameter uji 5-10\% (Hanafiah, 2016). Data kualitas air dianalisis secara deskriptif.

\section{Hasil}

\section{Pertumbuhan Panjang Mutlak}

Pertumbuhan panjang mutlak merupakan jumlah pertumbuhan berat pada larva ikan lele sangkuriang selama proses pemeliharaan (30 hari). Hasil pengamatan panjang mutlak yang diperoleh dalam penelitian ini disajikan dalam Gambar 4.

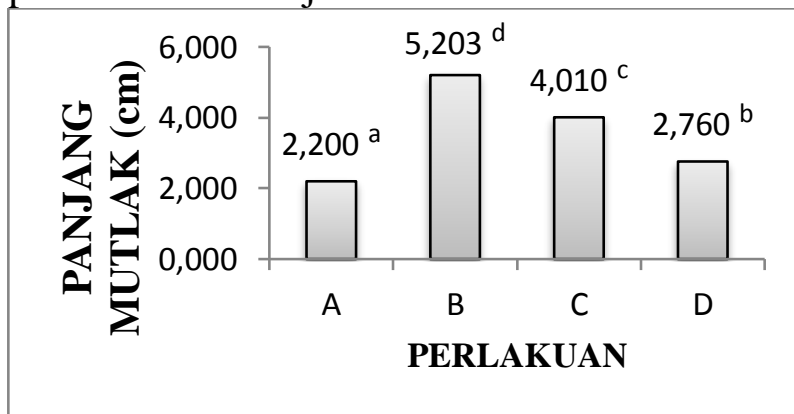

Gambar 1. Grafik Hubungan Antara Perlakuan dan Panjang Mutlak

Keterangan:*Notasi yang berbeda menunjukkan hasil yang berbeda nyata pada taraf $5 \%$.

Gambar 1. menunjukkan bahwa pemeliharaan larva lele sangkuriang (Clarias gariepinus) dengan penambahan 
cacing sutra (Tubifex) sebagai kombinasi pakan buatan memberikan pertumbuhan panjang mutlak tertinggi pada perlakuan B yaitu sebesar $5,20 \mathrm{~cm}$, selanjutnya diikuti perlakuan C sebesar 4,01 cm kemudian perlakuan D sebesar $2,76 \mathrm{~cm}$, sedangkan pertumbuhan panjang mutlak terendah pada perlakuan A yaitu sebesar $2,20 \mathrm{~cm}$. Berdasarkan hasil analysis of variance (ANOVA) dikatakan bahwa penambahan cacing sutra (Tubifex) sebagai kombinasi pakan buatan berpengaruh nyata (signifikan) terhadap pertumbuhan panjang mutlak larva ikan lele sangkuriang (Clarias gariepinus) (F hitung > F tabel), sehingga dilakukan uji lanjut untuk mengetahui perbedaan antar setiap perlakuan.

Nilai Koefisien Keseragaman (KK) sampel <5 (0,666352), sehingga uji lanjut yang digunakan yaitu uji BNT (Beda Nyata Terkecil). Hasil yang didapatkan menunjukkan bahwa penambahan cacing sutra (Tubifex) sebagai kombinasi pakan buatan pada pertumbuhan panjang mutlak larva ikan lele sangkuriang (Clarias gariepinus) berbeda nyata pada setiap perlakuan A, B, C dan D. Hal tersebut disebabkan karena cacing sutra memiliki kandungan protein sebesar $57 \%$ sedangkan pakan pelet memiliki kandungan protein sebesar $32 \%$, lemak $5 \%$, serat kasar sebesar $4 \%$ dan kadar air sebesar $12 \%$. Kandungan protein dan lemak dalam pakan dapattercukupi sehingga pertumbuhan terjadi.Penambahan cacing sutrapada pakan memberi rangsangan bagi ikan untuk dimakan.Ukurannya sesuai dengan bukaan mulut larva ikan lele sangkuriang dan mempunyai kandungan protein yang tinggi.Cacing sutra juga tidak mempunyai kerangka skeleton sehingga mudah dan cepat dicerna dalam usus ikan.Bau dan warna cacing Tubifex sp. juga merangsang ikan untuk dimakan, hal tersebut dapat dilihat secara langsung selama masa penelitian, dimana sewaktu pemberian pakan pelet, respon ikan lebih rendah daripada perlakuan pemberian pakan Tubifex.
Menurut Bokings et al. (2017), pakan merupakan salah satu faktor yang berperan dalam pertumbuhan ikan. Semakin tinggi kandungan gizi pakan maka akan baik untuk pertumbuhan ikan. Protein memegang peranan penting dalam penyusunan jaringan dan organ tubuh hewan, termasuk ikan.Dalam pakan yang diberikan kepada ikan, protein harus tersedia dalam jumlah yang cukup. Tingkat protein pakan yang rendah akan mengakibatkan pertumbuhan menjadi lambat.

Menurut pernyataan Effendie (1997) dalam Anggrailiyana (2017), pertumbuhan merupakan penambahan ukuranpanjang atau berat ikan dalam kurun waktu tertentu yang dipengaruhi oleh pakan,umur dan ukuran ikan.Pertumbuhan ikan lele sangkuriang dipengaruhi oleh dua faktor yaitu internal dan eksternal.Menurut Standar Nasional Indonesia, faktor internal merupakan faktor-faktor yang berhubungan dengan ikanseperti umur dan sifat genetik ikan (keturunan, kemampuan memanfaatkan makanan dan ketahanan terhadap penyakit). Faktor eksternal merupakan faktor yang berkaitan denganlingkungan tempat hidup ikan meliputi sifat fisika dan kimia air, ruang gerak danketersediaan makanan dari segi kualitas dan kuantitas.

\section{Pertumbuhan Berat Mutlak}

Berdasarkan hasil penelitian, pertumbuhan berat mutlak larva ikan lele sangkuriang (Clarias gariepinus) selama pemeliharaan 30 hari dapat dilihat pada gambar 5.

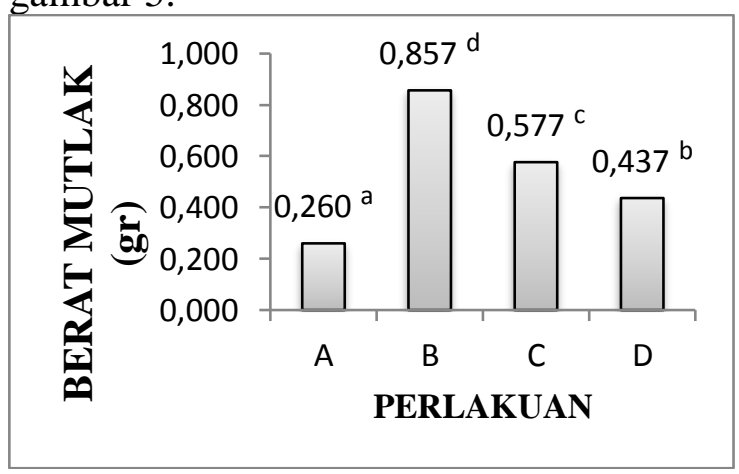


Gambar 2. Grafik Hubungan Antara Perlakuan dan Berat Mutlak

$$
\begin{gathered}
\text { Keterangan: } \\
\text { Notasi } \quad \text { yang } \\
\text { menunjukkan hasil yang berbeda } \\
\text { nyata pada taraf } 5 \% .
\end{gathered}
$$

Gambar 2. menunjukkan bahwa pemeliharaan larva lele sangkuriang (Clarias gariepinus) dengan penambahan cacing sutra (Tubifex) sebagai kombinasi pakan buatan memberikan pertumbuhan berat mutlak tertinggi pada perlakuan B yaitu sebesar 0,85 gr, selanjutnya diikuti perlakuan $\mathrm{C}$ sebesar 0,57 gr kemudian perlakuan D sebesar 0,43 gr, sedangkan pertumbuhan panjang mutlak terendah pada perlakuan A yaitu sebesar 0,26 gr.

$\begin{array}{crr}\text { Hasil uji analysis } & \text { variance } \\ \text { (ANOVA) menunjukkan } & \text { bahwa } \\ \text { penambahan cacing sutra } & \text { (Tubifex) } \\ \text { sebagai kombinasi pakan } & \text { buatan }\end{array}$
berpengaruh nyata (signifikan) terhadap pertumbuhan berat mutlak larva ikan lele sangkuriang (Clarias gariepinus) (F hitung $>\mathrm{F}$ tabel), sehingga dilakukan uji lanjut untuk mengetahui perbedaan antar setiap perlakuan.

Nilai Koefisien Keseragaman (KK) sampel <5 (1,092010), maka uji lanjut yang digunakan yaitu uji BNT (Beda Nyata Terkecil). Hasil analisis ini menunjukkan bahwa penambahan cacing sutra (Tubifex) sebagai kombinasi pakan buatan pada pertumbuhan berat mutlak larva ikan lele sangkuriang (Clarias gariepinus) berbeda nyata pada setiap perlakuan A, B, C dan D. Hal tersebut disebabkan karena cacing sutra memiliki kandungan protein dan lemak yang lebih tinggi dibandingkan dengan pakan pelet yang mengandung protein sebesar $32 \%$, lemak sebesar $5 \%$, serat kasar sebesar $4 \%$ dan kadar air sebesar $12 \%$. Menurut Suhenda et al. (2003)dalam Bokings et al. (2017), tingginya pertumbuhan larva ikan lele sangkuriang yang diberi penambahancacing sutrapada pakan dapat juga dipengaruhi oleh daya cerna ikan tersebut. Ikan lele sangkuriang merupakan ikan karnivora dimana ikan karnivora lebih mudah mencerna protein dan lemak, sehingga kandungan protein dan lemak yang tinggi turut berperan dalam pertumbuhan larva ikan lele sangkuriang.

Kandungan kisaran protein total pada setiap perlakuan berbeda-beda yaitu pada perlakuan A (pelet 100\%) mengandung kisaran protein total sebesar 32\%, perlakuan B (pelet $25 \%$ dan cacing sutra $75 \%$ ) mengandung kisaran protein total sebesar $50,75 \%$, perlakuan C (pelet $50 \%$ dan cacing sutra 50\%) mengandung kisaran protein total sebesar $44,5 \%$, dan pada perlakuan D (pelet $75 \%$ dan cacing sutra $25 \%$ ) mengandung kisaran perotein sebesar 38,25\%. Hal tersebut juga mempengaruhi pertumbuhan berat mutlak dari larva ikan lele dikarnakan semakin banyak protein yang mengandung dalam pakan ikan dapat mempercepat laju pertumbuhan ikan tersebut, seperti yang dinyatakan oleh Bokings et al. (2017), pakan yang diberikan dengan melihat kandungan protein menghasilkan linier positif terhadap pertumbuhan berat mutlak. Hal ini menunjukkan bahwa, semakin tinggi protein yang diberikan maka semakin tinggi pula pertumbuhan berat mutlaknya.

\section{Tingkat Kelangsungan Hidup/Survival Rate (SR)}

Tingkat kelangsungan hidup (SR) merupakan nilai perbandingan antara jumlah organism yang hidup diakhir pemeliharaan dengan jumlah organism saat penebaran yang dinyatakan dalam persen (\%). Semakin besar nilai persentase menunjukkan semakin banyak organism yang hidup selama pemeliharaan. Tingginya tingkat kelangsungan hidup pada suatu kegiatan budidaya, dapat diartikan sebagai suatu keberhasilan dalam kegiatan pemeliharaan yang dilakukan. Hasil penelitian tingkat kelangsungan hidup larva ikan lele sangkuriang (Clarias gariepinus) yang diperoleh disajikan pada Gambar 3. 


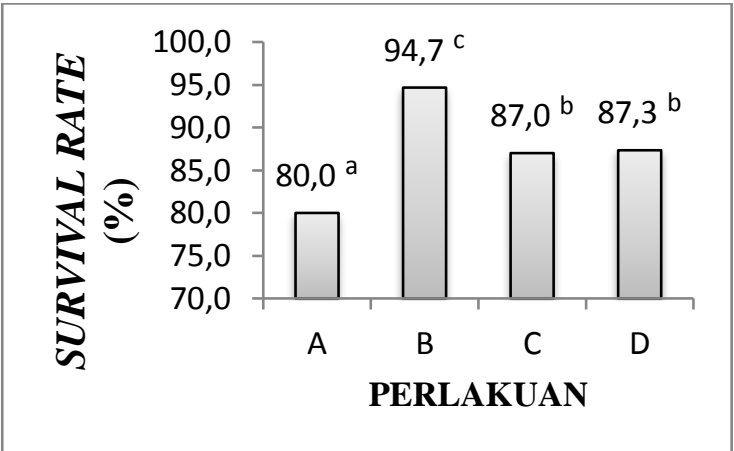

Gambar 3. Grafik Hubungan Antara Perlakuan dan Survivel Rate (SR)

Keterangan:*Notasi yang berbeda menunjukkan hasil yang berbeda nyata pada taraf $5 \%$.

Hasil pengamatan tingkat kelangsungan hidup (SR) larva lele sangkuriang (Clarias gariepinus) selama penelitian menunjukkan hasil yang bervariasi. Tingkat kelangsungan hidup tertinggi diperoleh pada perlakuan Byaitu sebesar 94,7 \% selanjutnya diikuti perlakuan Dyaitu sebesar $87,3 \%$, kemudian perlakuan $\mathrm{C}$ sebesar $87,0 \%$ dan nilai kelangsungan hidup terendah pada perlakuan A yaitu sebesar 80,0 \% . Hal tersebut dikarnakan cacing sutra merupakan pakan alami yang mudah dicerna oleh larva ikan lele sangkuriang sehingga dapat mempertahankan kelangsungan hidup larva ikan lele. Hasil uji analysis variance (ANOVA) menunjukkan bahwa penambahan cacing sutra (Tubifex) sebagai kombinasi pakan buatan berpengaruh nyata (signifikan) terhadap kelangsungan hidup (SR) larva ikan lele sangkuriang (Clarias gariepinus) (F hitung $>\mathrm{F}$ tabel), sehingga dilakukan uji lanjut untuk mengetahui perbedaan antar setiap perlakuan.

Nilai Koefisien Keseragaman (KK) sampel <5 (3,010839), maka uji lanjut yang digunakan yaitu uji BNT (Beda Nyata Terkecil). Hasil analisis ini menunjukkan bahwa penambahan cacing sutra (Tubifex) sebagai kombinasi pakan buatan pada pertumbuhan berat mutlak larva ikan lele sangkuriang (Clarias gariepinus), perlakuan A berbeda nyata dengan Perlakuan B, C dan D, perlakuan B berbeda nyata dengan perlakuan $\mathrm{A}, \mathrm{C}$ dan $\mathrm{D}$, sedangkan perlakuan $\mathrm{C}$ dan $\mathrm{D}$ tidak berbeda nyata. Hal ini disebabkan oleh kandungan gizi dari pakan yang diberikan. Berdasarkan hasil penelitian nilai kelangsungan hidup tertinggi ditemui pada perlakuan B $(75 \%$ cacing sutra dan $25 \%$ pellet). Menurut Bokings et al (2017), cacing sutra merupakan pakan alami yang sesuai untuk benih ikan karena pakan alami mudah dicerna dan mengandung gizi yang tinggi. Kandungan protein yang terdapat pada cacing sutra (Tubifex) yaitu sebesar $57 \%$. pakan yang mempunyai nutrisi yang baik sangat berperan dalam mempertahankan kelangsungan hidup.

Menurut penelitian Nurhayati et al.(2014),Kelangsungan hidup pada perlakuan pemberian pakan buatan lebih rendah dibandingkan dengan perlakuan lain. Hal ini berkorelasi dengan sistem pencernaannya yang masih sederhana dan belum berdiferensiasi baik secara morfologis maupun fisiologis sehingga kemampuan larva untuk mencerna pakan buatan lebih rendah dan menyebabkan kematian yang tinggi.Diperkirakan sebagian besar pakan yang dimakan larva justru mengganggu pencernaan, karena sistem pencernaannya belum sempurna dan masih banyak memerlukan enzim dari luar tubuh.

\section{Efisiensi Pemanfaatan Pakan (EPP)}

Hasil penelitian efisiensi pemanfaatan pakan (EPP) pada larva ikan lele sangkuriang (Clarias gariepinus) selama 30 hari tersaji dalam Gambar 4.

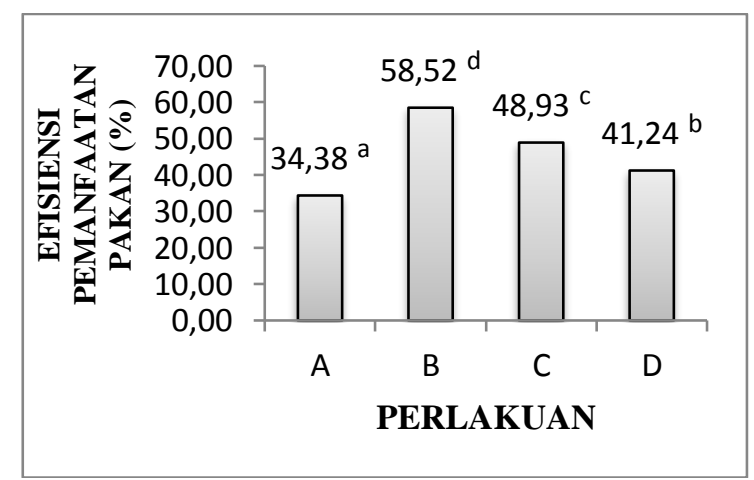


Gambar 4. Grafik Hubungan Antara Perlakuan dan Efisiensi Pemanfaatan Pakan

$$
\begin{gathered}
\text { Keterangan: } \\
\text { Notasi yang berbeda } \\
\text { menunjukkan hasil yang berbeda } \\
\text { nyata pada taraf } 5 \% .
\end{gathered}
$$

Hasil pengamatan efisiensi pemanfaatan pakan (EPP) larva lele sangkuriang (Clarias gariepinus) selama penelitian menunjukkan hasil yang bervariasi. Nilai efisiensi pemanfaatan pakan tertinggi diperoleh pada perlakuan Byaitu sebesar 58,52\% selanjutnya diikuti perlakuan Cyaitu sebesar 48,93\%, kemudian perlakuan D sebesar $41,24 \%$ dan nilai efisiensi pemanfaatan pakan terendah pada perlakuan A yaitu sebesar 34,38\%. Berdasarkan hasil uji analysis variance (ANOVA) menunjukkan bahwa penambahan cacing sutra (Tubifex) sebagai kombinasi pakan buatan berpengaruh nyata (signifikan) terhadap efisiensi pemanfaatan pakan (EPP) larva ikan lele sangkuriang (Clarias gariepinus) (F hitung $>\mathrm{F}$ tabel), sehingga dilakukan uji lanjut untuk mengetahui perbedaan antar setiap perlakuan.

Nilai Koefisien Keseragaman (KK) sampel > 5-10 (7,998189), maka uji lanjut yang digunakan yaitu uji BNT (Beda Nyata Terkecil). Hasil analisis ini menunjukkan bahwa penambahan cacing sutra (Tubifex) sebagai kombinasi pakan buatan pada efisiensi pemanfaatan pakan (EPP) larva ikan lele sangkuriang (Clarias gariepinus) berbeda nyata pada setiap perlakuan A, B, C dan D. Hal ini dikarnakan beberapa faktor seperti jenis serta kualitas dari pakan yang diberikan pada ikan, semakinbaik kualitas pakan yang diberikan maka akan membuat nilai efisiensi pemanfaatan pakan. Menurut Isnawati et al. (2015)dalam Karimah et al. (2018), pakan yang dimakan ikan akan diproses dalam tubuh dan unsur-unsur nutrisi atau gizinya akan diserap untuk dimanfaatkan membangun jaringan sehingga terjadi pertumbuhan. Laju pertumbuhan ikan sangat dipengaruhi oleh jenis dan kualitas pakan yang diberikan.
Pakan yang berkualitas baik akan menghasilkan pertumbuhan ikan dan efisiensi pakan yang tinggi. Secara ekonomis efisiensi pakan yang tinggi akan mempengaruhi biaya pakan sehingga berpengaruh pada biaya produksi. Efisiensi pakan yang tinggi menunjukkan penggunaan pakan yang efisien, sehingga hanya sedikit zat makanan yang dirombak untuk memenuhi kebutuhan energi dan selebihnya digunakan untuk pertumbuhan.Efisiensi pakan merupakan ratio antara pertambahan bobot dengan jumlah pakan yang dibetikan selama penelitian.

Efisiensi pemanfaatan pakan juga dapat dipengaruhi oleh laju pengosongan lambung, semakin cepat lambung dari ikan mencerna pakan yang diberikan maka akan meningkatkan nilai efisiensi pemanfaatan pakan. Menurut Zahrah (2014)dalam Karimah et al. (2018), konsumsi pakan secara langsung dikaitkan dengan kapasitas tampung lambung yang tersedia, sehingga berhubungan langsung dengan kecernaan dan laju pengosongan lambung. Semakin tinggi kemampuan cerna nutrien maka akan mempercepat lajupengosongan lambung, sehingga jumlah konsumsi pakan meningkat. Menurunnya kecernaan menyebabkan jumlah pakan yang tercerna semakin sedikit. Hal ini diduga akan memperlambat laju pengosongan lambung, sehingga berdampak pada jumlah konsumsi pakan yang menurun.

\section{Waktu Pengosongan Lambung}

Berdasarkan penelitian waktu pengosongan lambung larva ikan lele sangkuriang (Clarias gariepinus) didapatkan hasil yang disajikan pada Gambar 8. 


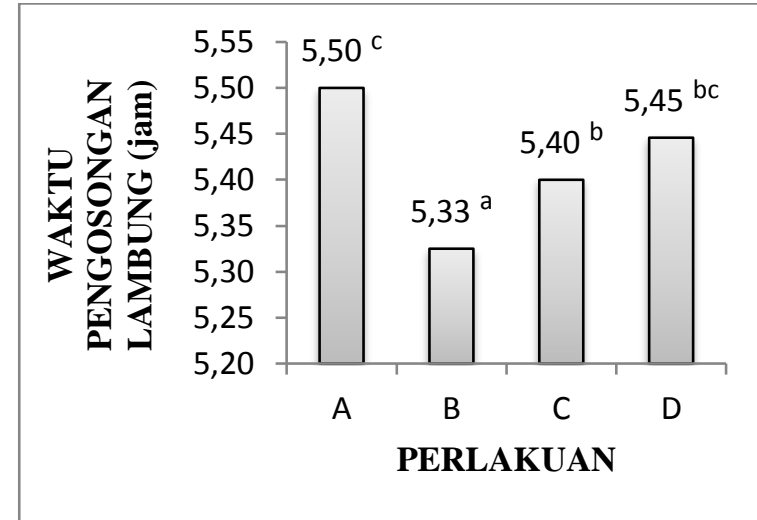

Gambar 5. Grafik Hubungan Antara Perlakuan dan Waktu Pengosongan Lambung

Keterangan:*Notasi yang berbeda menunjukkan hasil yang berbeda nyata pada taraf $5 \%$.

Berdasarkan hasil pengamatan waktu pengosongan lambung (WPL) larva lele sangkuriang (Clarias gariepinus) selama penelitian menunjukkan hasil yang bervariasi. waktu pengosongan lambung tertinggi diperoleh pada perlakuan Ayaitu 5 jam 50 menit selanjutnya diikuti perlakuan Dyaitu 5 jam 45 menit kemudian perlakuan C yaitu 5 jam 40 menit dan waktu pengosongan lambung terendah pada perlakuan D yaitu 5 jam 33 menit. Berdasarkan hasil uji analysis variance (ANOVA) menunjukkan bahwa penambahan cacing sutra (Tubifex) sebagai kombinasi pakan buatan berpengaruh nyata (signifikan) terhadap waktu pengosongan lambung (WPL) larva ikan lele sangkuriang (Clarias gariepinus) (F hitung > F tabel), sehingga dilakukan uji lanjut untuk mengetahui perbedaan antar setiap perlakuan.

Nilai Koefisien Keseragaman (KK) sampel < $5(0,272956)$, maka uji lanjut yang digunakan yaitu uji BNT (Beda Nyata Terkecil). Hasil analisis ini menunjukkan bahwa penambahan cacing sutra (Tubifex) sebagai kombinasi pakan buatan pada waktu pengosongan lambung larva ikan lele sangkuriang (Clarias gariepinus), perlakuan A berbeda nyata dengan perlakuan $\mathrm{B}$ dan $\mathrm{C}$ tetapi tidak berbeda nyata dengan perlakuan D.
Perlakuan B berbeda nyata dengan perlakuan A, C dan D. Perlakuan C berbeda nyata dengan perlakuan $\mathrm{A}$ dan $\mathrm{B}$ tetapi tidak berbeda nyata dengan perlakuan D. Hal ini disebabkan beberapa faktor seperti jenis dan kualitas pakan yang diberikan pada ikan. Perlakuan paling baik yaitu perlakuan B (pelet $25 \%$ dan cacing sutra 75\%) selama 5 jam 33 menit, hal ini dikarnakan cacing sutra tidak mempunyai kerangka skeleton sehingga dapat dengan cepat dicerna oleh usus ikan.

Perlakuan paling rendah yaitu pada perlakuan A $(100 \%)$ pelet. Hal ini disebabkan karena sistem pencernaan dari larva ikan lele sangkuriang masih sederhana sehingga kemampuan larva untuk mencerna pakan buatan masih rendah. Pelet yang diberikan pada larva ikan mengandung protein sebanyak $32 \%$, lemak sebanyak $5 \%$, serat kasar sebanyak $4 \%$ serta kadar air sebanyak $12 \%$. Menurut Zidni et al. (2018), kenaikan presentase nilai laju digesti dikarenakan jumlah pakan yang diberikan mendekati kapasitas tampung lambung ikan sehingga pakan yang diberikan dapat dikonsumsi dan dicerna dengan sempurna oleh ikan. Laju digesti pada umumnya berkolerasi dengan laju metabolisme ikan. Semakin lama waktu, maka isi lambung akan semakin berkurang sehingga bobot tubuh ikan berkurang. Waktu pengosongan lambung dipengaruhi juga oleh pakan yang dikonsumsi oleh ikan.

Berdasarkan hasil pengamatan dapat dilihat bahwa waktu pengosongan lambung dari larva ikan lele sangkuriang tidak terlalu optiman yang dikarnakan suhu air tidak terlalu optimal untuk budidaya larva ikan lele yaitu $21-24{ }^{\circ} \mathrm{C}$, dimana menurut pendapat dari Benedictus (2013), laju pengosongan lambung pada benih ikan lele Sangkuriang mencapaipuncaknya pada menit ke 240 - 270 atau $4-4,5$ jam setelah proses makandimulai. Menurut Zidni et al. (2018), suhu air yang meningkat memicu nafsu makan ikan juga mengalami peningkatan, sedangkan apabila terjadi penurunan temperatur air maka nafsu 
makan ikan juga akan mengalami penurunan. Kondisi temperatur yang optimal bagi ikan juga akan menyebabkan laju metabolisme meningkat.Menurut Afifi (2014) dalam Sianturi (2018), menyatakan bahwa ikan lele memiliki toleransi terhadap suhu $22-34^{\circ} \mathrm{C}$.

\section{Kualitas Air}

Kualitas air mempunyai peranan penting sebagai pendukung kehidupan dan pertumbuhan larva ikan lele sangkuriang (Clarias gariepinus). Hasil pengamatan terhadap parameter kualitas air yang meliputi suhu, $\mathrm{pH}, \mathrm{DO}$, dan amonia pada semua perlakuan disajikan pada Tabel 1. Tabel 1. Parameter Kualitas Air

\begin{tabular}{ccccc}
\hline Parameter & \multicolumn{3}{c}{ Perlakuan } \\
\cline { 2 - 5 } & $\mathrm{A}$ & $\mathrm{B}$ & $\mathrm{C}$ & $\mathrm{D}$ \\
\hline Suhu & $21-24$ & $21-24$ & $21-$ & $21-24$ \\
& & & 24 & \\
pH & $6,7-$ & $6,8-$ & $6,9-$ & $6,7-$ \\
& 7,6 & 7,8 & 7,8 & 7,8 \\
DO & $4,4-5$ & $4,2-$ & $4,5-5$ & $4,2-$ \\
& & 4,7 & & 5,2 \\
Amonia & $<0,01-$ & $<0,01-$ & $0,01-$ & $<0,01-$ \\
& 0,71 & 2,5 & 2,6 & 2,2 \\
\hline
\end{tabular}

Dari Tabel 1. di atas dapat dilihat suhu yang terdapat pada tiap wadah pemeliharaan larva ikan lele sangkuriang selama penelitian berkisar antara $21-24^{\circ} \mathrm{C}$. Perubahan suhu terjadi disebabkan oleh tidak menentunya cuaca selama proses pemeliharaan. Suhu pada setiap perlakuan tergolong agak rendah untuk pemeliharaan larva ikan lele sangkuriang.Menurut Afifi (2014) dalam Sianturi (2018), menyatakan bahwa ikan lele memiliki toleransi terhadap suhu $22-34^{\circ} \mathrm{C}$. Suhu tersebut masih dalam batas toleran untuk larva ikan lele sangkuriang dalam bertahan hidup, menurut Madinawati et al. (2011) dalam Sitio et al. (2017), ikan lele dapathidup pada suhu air berkisar antara $20-30^{\circ} \mathrm{C}$.

Derajat keasaman $(\mathrm{pH})$ selama penelitian berkisar antara 6,7-7,6. Nilai $\mathrm{pH}$ sangat penting sebagai parameter kualitas air karena ikan dan biota air lainnya hidup pada kisaran $\mathrm{pH}$ tertentu. Menurut Boyd (1982) dalam Purwanti et al. (2014) dalamSitio et al. (2017), lele dapat tumbuh dengan baik pada kisaran $\mathrm{pH}$ antara 6,5-9. Menurut Effendi (2003)dalam Sitio et al. (2017), sebagian besar ikan dapat beradaptasi dengan baik pada lingkungan perairan yang mempunyai $\mathrm{pH}$ berkisar antara 5-9. Nilai $\mathrm{pH}$ yang terlalu rendah dan tinggi dapat menghambat proses pertumbuhan ikan bahkan dapat mengakibatkan kematian. Hasil penelitian menunjukkan nilai $\mathrm{pH}$ yang diperoleh sudah ideal untuk pertumbuhan dan kelangsungan hidup larva ikan lele sangkuriang.

Kisaran nilai DO selama pengamatan antara 4,2-5,2 mg/l, oksigen terlarut (DO) sangat diperlukan untuk respirasi dan metabolisme serta kelangsungan hidup ikan. Menurut Sitio et al. (2017),kadar oksigen yang baikuntuk menunjang pertumbuhan ikan lele secara optimum harus lebih dari $3 \mathrm{mg} / \mathrm{L}$.

Senyawa $\mathrm{NH}_{3}$ merupakan bentuk amonia bebas (tidak terionisasi) yang bersifat sangat toksik pada ikan. Amonia bersifat basa lemah sehingga kenaikan amonia akan memicu peningkatan nilai $\mathrm{pH}$. Peningkatan kadar amonia terutama berasal dari pemberian pakan yang berlebihan dan feses yang dihasilkan oleh ikan dan mengendap di dasar wadah pemeliharaan. Akibatnya, ekskresi amonia olehikan cukup tinggi. Kisaran nilai amonia selama penelitian antara $<0,01-2,5$ $\mathrm{mg} / \mathrm{l}$. kisaran nilai amonia tersebut masih dalam batas toleransi ikan lele, menurut Hastuti dan Subandiyono (2015) dalam Sitio et al. (2017), ikan lelemampu mentoleransi amonia sampai $5,70 \mathrm{mg} / \mathrm{L}$.

\section{Kesimpulan}

Kesimpulan yang dapat ditarik dari penelitian ini bahwa penambahan cacing sutra (Tubifex) sebagai kombinasi pakan buatan untuk pemeliharaan larva ikan lele sangkuriang (Clarias gariepinus) memberikan pengaruh nyata terhadap 
pertumbuhan berat mutlak, pertumbuhan panjang mutlak, tingkat kelangsungan hidup, efisiensi pemanfaatan pakan (EPP) dan waktu pengosongan lambung. Hasil penelitian menunjukkan bahwa perlakuan terbaik terdapat pada perlakuan B (Pelet $25 \%$ dan Cacing Sutra $75 \%$ ) dengan pertumbuhan berat mutlak sebesar 0,857gr, pertumbuhan panjang mutlak $5,203 \mathrm{~cm}$, kelangsungan hidup (SR) $94,7 \%$, efisiensi pemanfaatan pakan (EPP) $58,52 \%$ dan waktu pengosongan lambung 5 jam 33 menit.

Berdasarkan kesimpulan di atas maka saran yang dapat diajukan yakni, kombinasi cacing sutra (Tubifex) $75 \%$ dan pakan buatan $25 \%$ dapat meningkatkan efisiensi pemenfaatan pakan dan pertumbuhanuntuk pemeliharaan larva ikan lele sangkuriang (Clarias gariepinus). Perlu adanya penelitian lanjutan tentang perbandingan cacing sutra (Tubifex) dan pakan alami lainnya sebagai kombinasi pakan buatan (pelet) terhadap efisiensi pemanfaatan pakan (EPP), laju pertumbuhan, kelangsungan hidup dan nilai ekonomis dalam pemeliharaan larva ikan lele (Clarias gariepinus).

\section{Daftar Pustaka}

Anggrailiyana, Y. D. 2017. Pertumbuhan Benih Ikan Lele Sangkuriang (Clarias gariepinus) Pada Media Terkontrol. Skripsi.Universitas Negeri Semarang.

Anggrainy, L. 2015. Kombinasi Cacing Sutra Dan Pakan Buatan Yang Ditambah Probiotik Pada Pemeliharaan Larva Ikan Lele Clarias sp.. Skripsi, Institut Pertanian Bogor. Bogor.

Apriyana, I. 2013. Pengaruh Penambahan Tepung Kepala Ikan Lele (Clarias sp.) Dalam Pembuatan Cilok Terhadap KadarProtein dan Sifat Organoleptiknya.Skripsi.Universitas Negeri Semarang. Semarang.
Arief, M., Nur, F., Sri, S. 2014. Pengaruh Pemberian Probiotik Berbeda Pada Pakan Komersial Terhadap Pertumbuhan dan Efesiensi Pakan Ikan Lele Sangkuriang (Claria sp.).Jurnal Ilmu Perikanan dan Kelautan. 6 (1) : 49-53.

Benedictus, J. 2013. Optimalisasi Pertumbuhan Pada Pendederan Ikan Lele Sangkuriang (Clarias gariepinus) Melalui Pengaturan Frekuensi Pemberian Pakan.Skripsi.Institut Pertanian Bogor.

Bokings, U.L.Y., Koniyo., Juliana. 2017. Pertumbuhan Dan Kelangsungan Hidup Benih Ikan Patin Siam (Pangasius hypophthalmus) Yang Diberi Pakan Buatan, Cacing Sutra (Tubifex sp.) dan Kombinasi Keduanya. Jurnal Ilmiah Perikanan dan Ilmu Kelautan. 5 (3) : 82-89.

Elpawati, Dianna, R.P., Nani, R. 2015. Aplikasi Effective Microorganism 10 (Em10) Untuk Pertumbuhan Ikan Lele Sangkuriang (Clarias Gariepinus Var. Sangkuriang) Di Kolam Budidaya Lele Jombang, Tangerang.Jurnal Biologi, 8 (1) : 614.

Hanafiah, K. A. 2016. Buku: Rancangan Percobaan Teori \& Aplikasi Edisi Ketiga. Depok: PT RajaGrafindo Persada.

Idawati, Cut, N.D., Siska, M. 2018. Pengaruh Pemberian Pakan Alami Yang Berbeda Terhadap Pertumbuhan dan Kelangsungan Hidup Ikan Patin (Pangasius sp.). Jurnal Ilmiah Mahasiswa kelautan dan Perikanan Unsyah. 3 (1) : 14-22.

Karimah, U., Istyanto, S., Pinandoyo. Performa Pertumbuhan dan Kelangsungan Hidup Ikan Nila Gift 
(Oreochromis niloticus) Yang Diber Jumlah Pakan Yang Berbeda. Jurnal Of Aquaculture Management and Technology.7 (1) : 128-135.

KKP. (2019). Kkp Dorong Kawasan Lele Digital Pertama Di Indonesia. https://kkp.go.id/artikel/8989-kkpdorong-kawasan-lele-digitalpertama-di-indonesia. [14November 2019]

Nisrinah, Subandiyono., Tita, E. 2013. Pengaruh Penggunaan Bromelin Terhadap Tingkat Pemanfaatan Protein Pakan Dan Pertumbuhan Lele Dumbo (Clarias gariepinus). Journal of Aquaculture Management and Technology. 2 (2): 57-63.

Nurhayati, Nur, B.P.U., Mia, S. 2014. Perkembangan Enzim Pencernaan dan Pertumbuhan Larva Ikan Lele Dumbo, Clarias gariepinus Burchell 1822, Yang Diberi Kombinasi Cacing Sutra dan Pakan Buatan. Jurnal Ikhtiologi Indonesia.14 (3) : 167-178

Setiawati, E., Eko D., Rachimi.2014. Pengaruh Cacing Sutra (Tubifex) Dengan Frekuinsi Yang Berbeda Terhadap Pertumbuhan Ikan Tomat (Channa micropltes CV.).Jurnal Ruaya. 2 (1) : 59-64.

Sianturi, A. 2018. Pengaruh Waktu Pemberian Pakan Buatan Terhadap Pertumbuhan dan Kelangsungan Hidup Ikan Lele (Clarias Sp.). Skripsi.Unifersitas Sumatra Utara.

Sitio, M. H. F. 2017. Kelangsungan Hidup dan Pertumbuhan Benih Ikan Lele (Clarias Sp.)Pada Salinitas Media
Yang Berbeda.Jurnal Akuakultur Rawa Indonesia. 5 (1).

Standar Nasional Indonesia.2006. Pakan Buatan Untuk Ikan Lele Dumbo Clarias gariepinus) Pada Budidaya Intensif.Jakarta : Standar Nasional Indonesia. 01- 4087.

Zidni, I., Eddy A., Izza M., Heti H., Ibnu B.S. 2018. Laju Pengosongan Lambung Ikan Mas (Cyprinus carpio) dan Ikan Nila (Oreochromis niloticus).Jurnal Perikanan dan Kelautan. 9 (2) : 147-151. 